Institute of $\mathbf{F}_{\text {ood and }} \mathbf{A}_{\text {gricultural }} \mathbf{S}_{\text {ciences }}$

\title{
Water Table Measurement and Monitoring for Flatwoods Citrus 1
}

Brian Boman and Thomas Obreza ${ }^{2}$

\section{Introduction}

Most flatwoods citrus soils have a restrictive layer that can perch the water table and significantly affect tree water relations. To avoid off-site movement of nutrients, unnecessary pumping for irrigation or drainage, and to optimize production and tree health, the level of this water table should be monitored and maintained within an optimal zone.

There is a wide range in the cost of the many methods that have been used to measure water table levels. The cost of monitoring devices is directly related to the frequency with which measurements are taken and to the accuracy required. Methods range from a ruler used to measure water depth in an observation well to electronic sensors attached to data loggers. Although growers often would like detailed information on water table levels, simple and practical observation wells can normally produse adequate information. The costs associated with installation, operation, and maintenance of precision recording equipment is frequently too great to make such devices practical.

\section{Water Table Behavior}

Most Florida flatwoods soils are poorly-drained because of low elevation, flat landscape, and the restrictive layer that normally exists below the root zone. Consequently, flatwoods citrus is planted on raised soil beds in order to create an unsaturated soil volume for root growth and development. Therefore, the first goal of water table management is to promote drainage of excess water and avoid satuated conditions water in the root zone.

A high water table can exist close enough to the root zone to have a direct influence on the vigor and productivity of citrus trees when planted on raised beds. Rainfall and irrigation can quickly raise the water table, while slope, topographical elevation, depth to the restrictive layer, and the ability of the artificial drainage system to remove water influence how quickly the water table declines.

Although improper water table management can result in a high water table that is detrimental to tree health, a properly managed water table can provide a significant portion of the tree's water needs through upflux from a water table below the root zone.

1. This is Circular 1409, Florida Cooperative Extension Service, Institute of Food and Agricultural Sciences, University of Florida. Publication date: July 2002. Please visit the EDIS Web site at http://edis.ifas.ufl.edu for additional publications related to citrus water management. This document can be accessed as http://edis.ifas.ufl.edu/CH151.

2. B. J. Boman, Associate Professor, Department of Agricultural and Biological Engineering, Indian River REC-Ft. Pierce and T. A. Obreza, Professor, Soil and Water Science Department, Sourhwest Florida REC-Immokalee. University of Florida Cooperative Extension Service, Institute of Food and Agricultural Sciences, Gainesville, FL 32611.

The Institute of Food and Agricultural Sciences is an equal opportunity/affirmative action employer authorized to provide research, educational information and other services only to individuals and institutions that function without regard to race, color, sex, age, handicap, or national origin. For information on obtaining other extension publications, contact your county Cooperative Extension Service office. Florida Cooperative Extension Service/Institute of Food and Agricultural Sciences/University of Florida/Christine Taylor Waddill, Dean. 
Managing the water table properly will enhance tree growth and production and is usually cost effective.

Flatwoods citrus groves are normally planted with one to four rows per bed. Since the beds are crowned to aid surface water drainage to water furrows, bed configuration can influence water table behavior beneath individual rows. With single and double-row beds, the tree rows are usually at the same elevation above the bottom of the water furrows, so the resident water table depth is about the same beneath each tree. However, the center row or rows on 3- or 4-row beds are higher above the water furrow than the edge rows (Fig. 1), so there can be a greater vertical distance between the water table and the root zone under the middle rows. A difference of even a few inches in tree row elevation can cause a large difference in the root zone water regime, which can effect long-term tree growth and productivity. Water table depth differences between the middle and edge rows on 3 or 4-row beds typically differ by 4 to 6 inches throughout the year (Fig. 2).

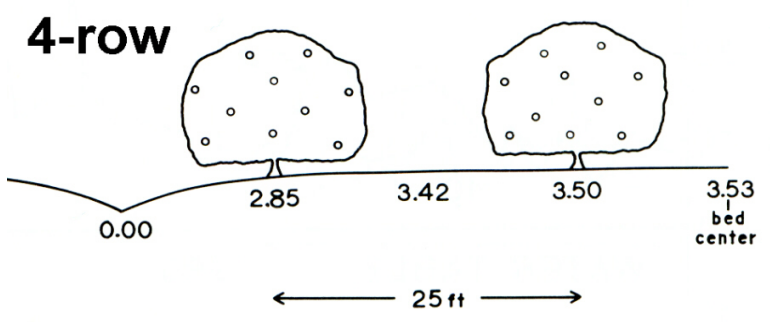

\section{3-row}

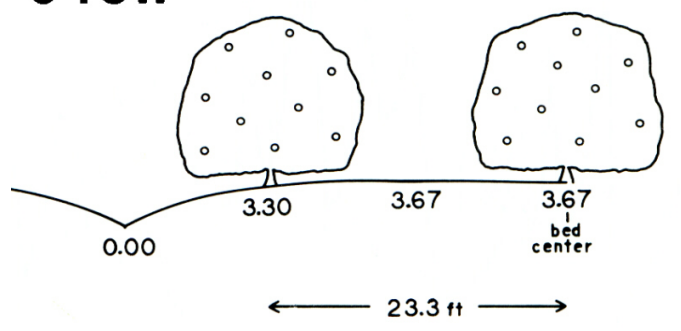

Figure 1. Examples of multi-row bed configurations in flatwoods citrus. Numbers indicate the vertical distance in feet above the water furrow.

The water table under flatwoods citrus may rise rapidly in response to either rainfall or irrigation because sandy soils are highly conductive to water flow (Fig. 3 and Fig. 4). A general rule of thumb is that 1 inch of rain will cause the water table to rise about 10 inches in fine textured soils, 6 inches in most of the flatwoods sandy soils, and 4 inches in coarse sands. It may take 4 to 6 days for the water table to return to its desired levels following rains of 1 inch or more.

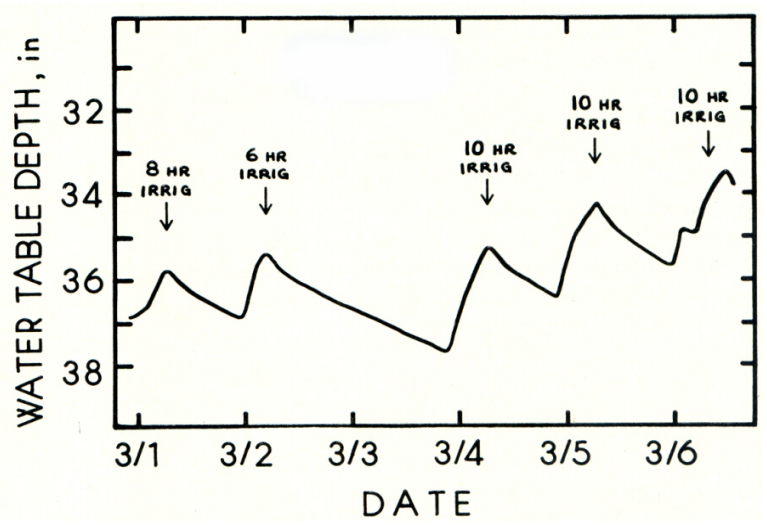

Figure 3. Example of water table depth response to extended periods of drip irrigation in bedded flatwoods citrus.

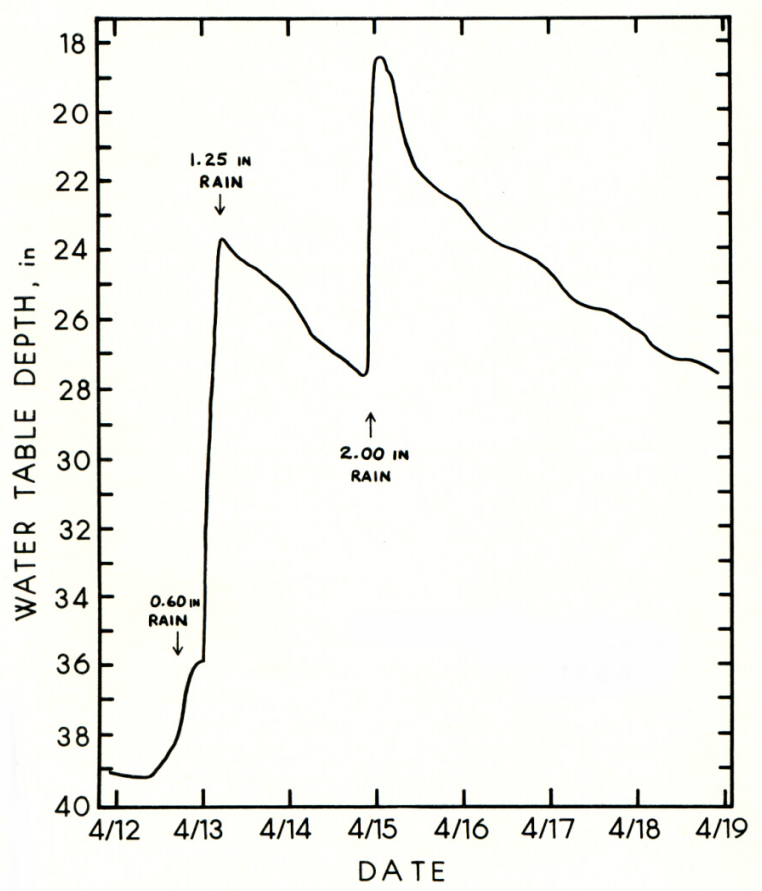

Figure 4. Example of water table depth response to rainfall in bedded flatwoods citrus.

Because of high porosity and high hydraulic conductivity in sandy flatwoods soils, it is possible for drip irrigation to raise the water table under a citrus bed if the irrigation system is run for a long time (Fig. 5). Lateral water movement outward from a drip emitter may be only 6 to 8 inches, thus much of the applied water moves downward in a small cylindrical wetted pattern. It may not take long for water to reach the free water surface of the water 

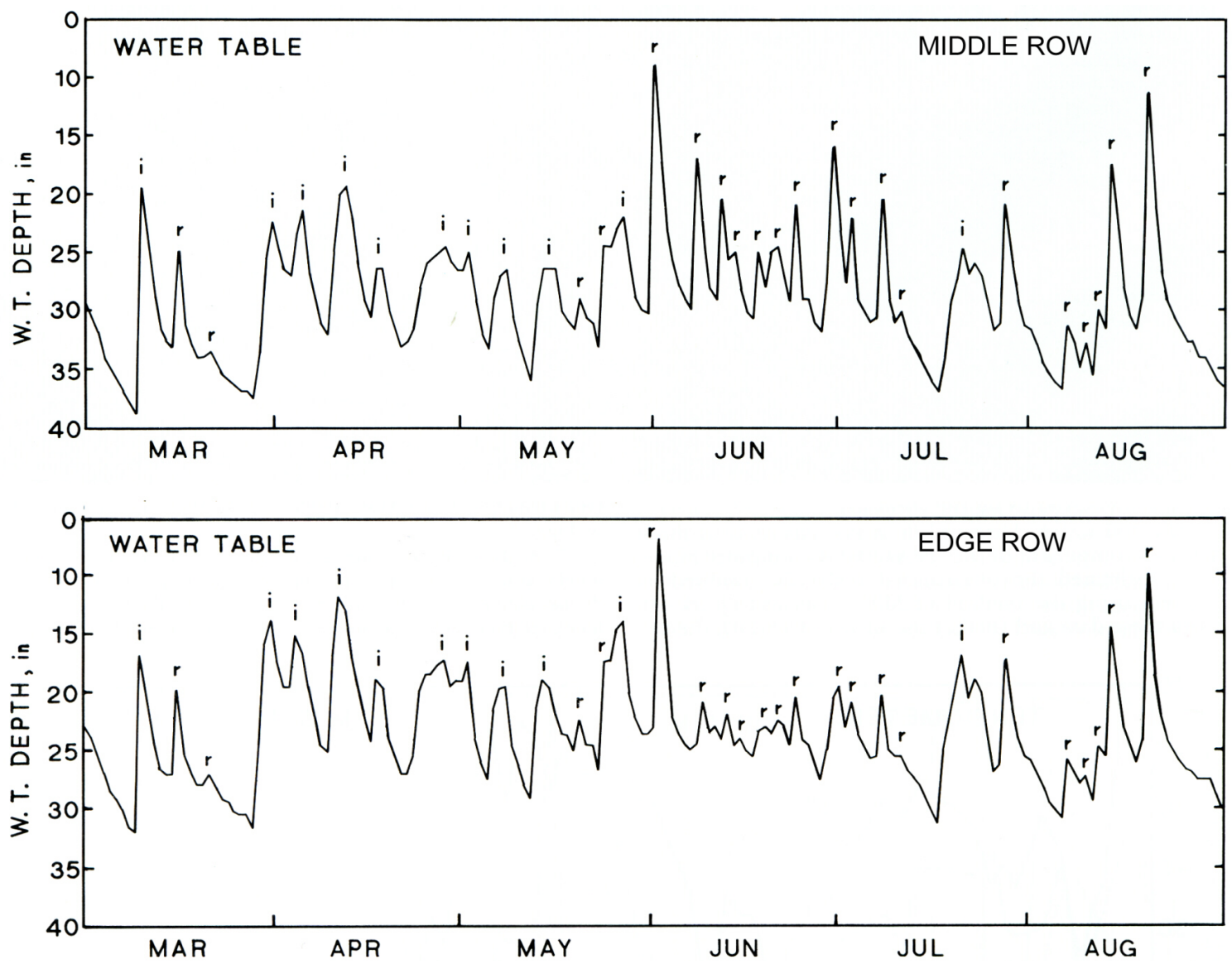

Figure 2. Water table fluctuations in response to seepage irrigation (i) and rainfall (r) under a 4-row citrus bed.

table and thereby cause the water table to rise. Even though the magnitude of rise may not be as great as with flood (seepage) irrigation, it is measurable with a simple water table observation well.

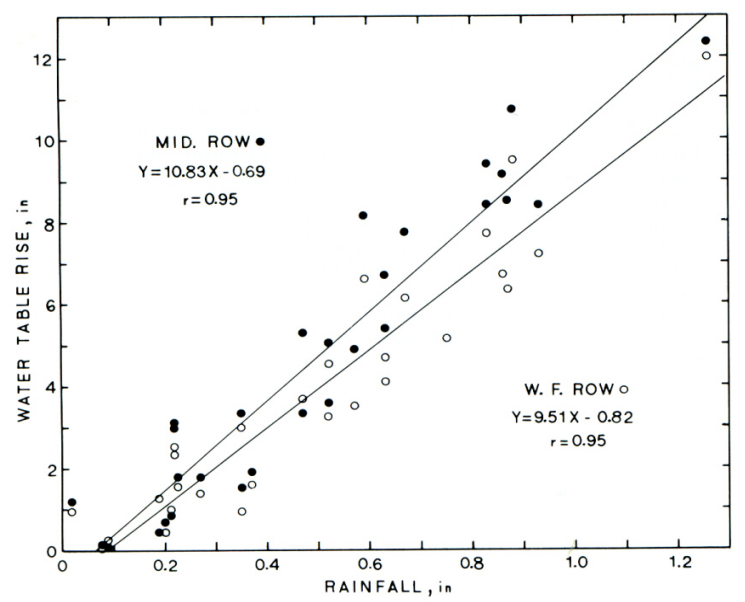

Figure 5. Magnitude of water table rise and with respect to rainfall volume under middle and water-furrow row positions in multi-row bedded flatwoods citrus.
If the intent of irrigation is to keep irrigation water from moving below the root zone, then water table observation wells should be useful to determine cycle times (duration). Some irrigation managers use drip irrigation as a method for water table management. A water table observation well should also be useful in this situation, especially if it was used in conjunction with a float switch that turns the irrigation system on and off as the water table fluctuats between desired minimum and maximum levels.

\section{Upflux}

The movement of water upward within the soil profile from the water table is called capillarity or upflux (Fig. 6). As water is removed from the soil by tree roots and by evaporation at the ground surface, water content of the soil decreases. By capillary action, water moves from the water table into the drier soil above. Water adheres to soil particles due to surface tension between adjacent particles. Smaller 
soil particles have smaller inter-particle voids (pore spaces). The smaller particles provide greater surface areas upon which water can adhere. In addition, the smaller pores allow water to be retained at higher surface tensions.

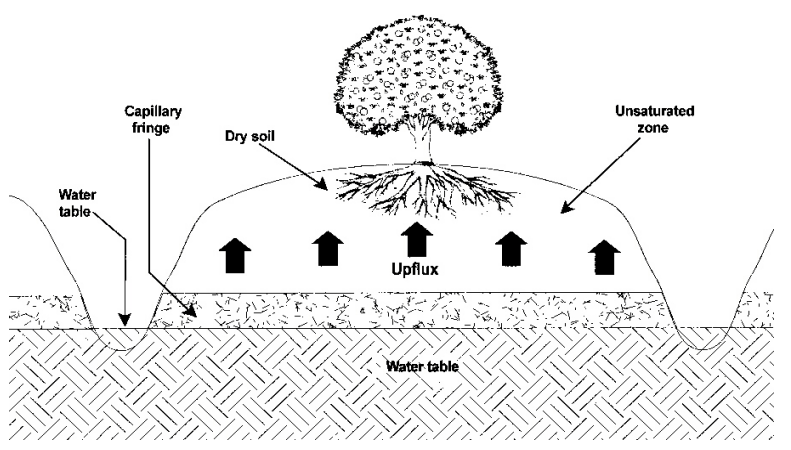

Figure 6. Schematic of upflux process in bedded citrus.

As a consequence, soils with smaller particle sizes have the ability to move water greater distances by capillary action than coarser soils (Figs. 7 and 8). As a result, the upflux process can move water into the root zone from a much deeper water table in clay soils than it can in sandy soils.

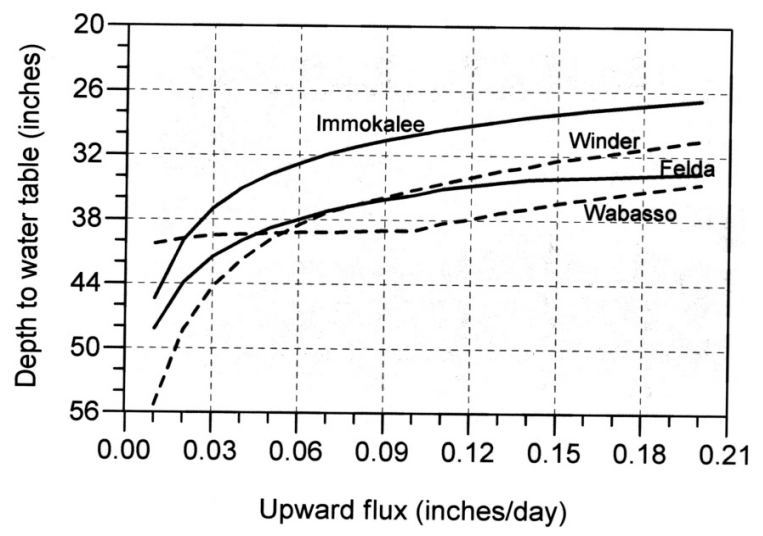

Figure 7. Typical upflux rates by water table depths for Immokalee, Winder, Felda, and Wabasso series soils (data from Obreza and Boman, 1992).

Water in excess of field capacity drains by gravity into the shallow water table after a saturating rain or irrigation cycle. The removal of soil water by evaporation and transpiration results in water movement upwards (upflux) by capillary action to replace some of the water in the root zone. The deeper the water table is, the farther the water has to travel upwards into the root zone. Therefore, the effectiveness of the water table for providing moisture to the roots decreases as the water table level drops. If the level is allowed to drop too low,

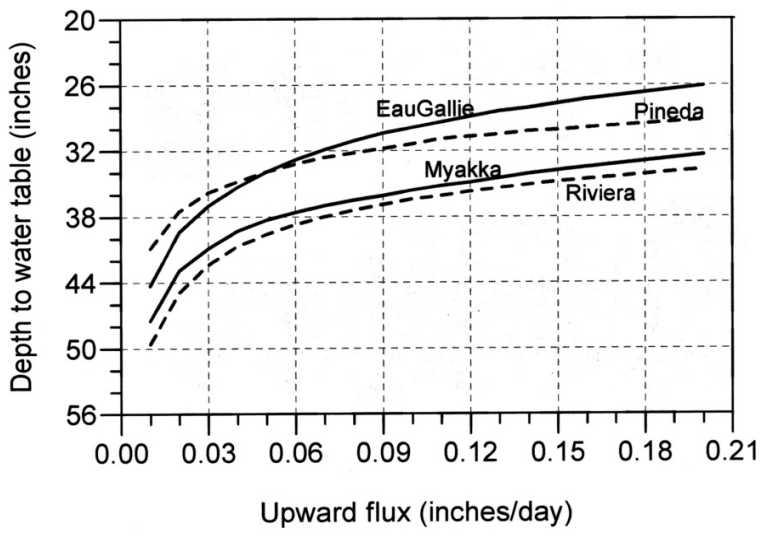

Figure 8. Typical upflux rates by water table depths for Eau Gallie, Myakka, Pineda, and Riviera series soils (data from Obreza and Boman, 1992).

capillarity is broken and upflux action ceases until another saturating rain or irrigation cycle refills the soil profile or the water table can be raised to re-establish capillarity.

\section{Observation Wells}

A water table observation well is made with a porous casing buried vertically in the ground. It permits the groundwater level to rise and fall inside it as the water level in the adjacent soils. Observation wells with a simple float indicator can provide rapid evaluation of shallow water table depths. The float and indicator level move with the water table, allowing an obove-ground indication of the water level.

Water table observation wells installed in flatwoods soils usually penetrate only to the depth of the restrictive (argillic or spodic) layer. Typically this layer is within 30 to 48 inches of the soil surface. Observation wells in these soils need water level indicators that respond to a minimal amount of recharge water so that even slight perching of the water table can be detected.

\section{$\underline{\text { Well Construction }}$}

The basic components of the well itself include a short section of 3-inch perforated PVC pipe (3-5 ft), 3-inch PVC cap, screening material, a float, indicator rod, and small stopper (Fig. 9).

The indicator rod can be a dowel, 1/2 -inch PVC pipe (thin wall) or microsprinkler extension stake. 


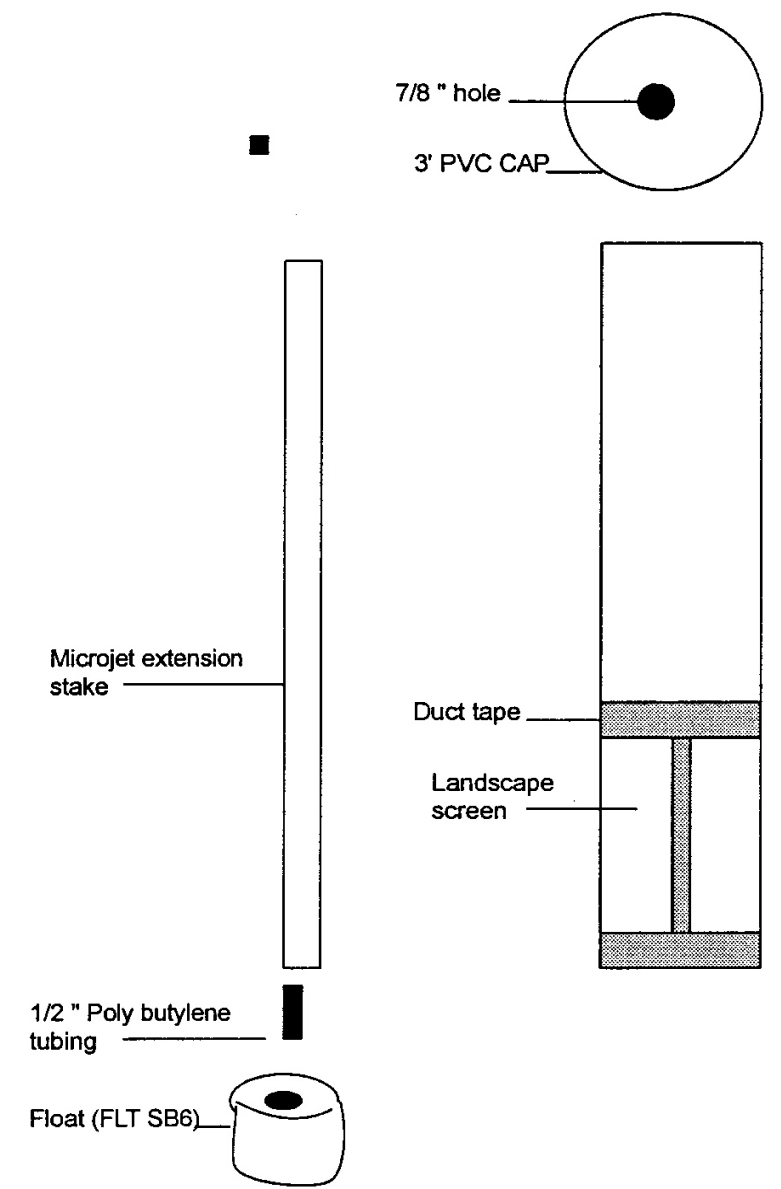

Figure 9. Typical components for shallow water table observation well.

Dowels are a poor choice since they require painting and will rot out near the float within a few years. The float is typically a $21 / 2$ - inch fishing net float or a 500 $\mathrm{ml}$ (approximately $21 / 2$ in. diameter $\mathrm{x} 6$ in. high) polyethylene bottle with a $28-\mathrm{mm}$ (1.1 in.) screw cap size. The float assembly can be constructed by inserting the microsprinkler extension stake into the fishing float or $1 / 2$-inch pipe into the polyethylene bottle.

The bottle neck provides a snug fit for the stake and no sealant is required. The hole in the cap should be drilled slightly larger than the indicator stake to serve as a guide for the float assembly. Fittings should not be glued so that components can be easily disassembled for cleaning or replacement.

Observation well casings are constructed from 3-in. diameter PVC pipe (Class 160). A circular saw or drill can be used to perforate the pipe prior to installation. Perforations should be staggered in rows around the pipe to allow flow into the well from the sides in addition to the bottom. Perforations totaling about $5 \%$ of the well's surface area are adequate for sandy soils encountered in the flatwoods. No perforations should be made within 12 inches of the surface in order to minimize the chances of ponded water from high intensity storms creating flow channels into perforations near the soil surface.

The pipe should be wrapped (sides and bottom) with a screening material to prevent soil particles from moving into the well. Materials such as cheesecloth, polyester drain fabric, and fiberglass screen have been used successfully as filters. The filter material should be taped in place with duct tape. A 3-inch soil auger can be used to bore holes for the wells. When possible, the observation wells should be installed when no water table is present in order to minimize chances of the well sides sloughing into the bore as it is dug.

When a water table is present, it is easiest to install the well by starting off with a larger diameter pipe. For a 3-inch observation well, a 4-inch installation pipe (Sch 40 preferred) will be needed. The installation pipe should be cut at least 6 inches longer than the intended depth of well.

Holes ( 1/2-inch diameter) should be drilled in the sides of the pipe opposite each other about $11 / 2$ inches from the top of the pipe. These will be used to aid in removing the pipe from the soil after the observation well is installed. Auger a hole in the soil until it begins to slough in (when the water table is reached). The 4-inch pipe should then be forced into the hole. A 3-inch auger can then be used to remove soil from within the 4-inch casing. As soil is removed, the casing needs to be forced downward to keep the hole from sloughing. Continue to remove soil from inside the casing until the appropriate depth is achieved (typically when hardpan material begins to be excavated).

The well casing pipe should be cut to length and installed in the hole so that it extends 2 to 6 inches above the soil surface. Care should be taken to ensure that the casing is installed plumb to minimize binding of the float assembly. If a 4-inch installation pipe was used to excavate the hole, it needs to be removed. A 1/2-inch rod can be inserted through the holes that 
were drilled in the top of the 4-inch pipe. If the pipe cannot be removed easily by hand, a chain can be attached to the rod and attached to a high-lift jack. Usually, after jacking the installation pipe up about a foot, the pipe can be easily removed by hand. The soil should be backfilled around the observation well casing and tamped to compact the soil and get a tight fit between the soil and the sides of the pipe.

A measurement should be taken of the distance from the bottom of the well to the soil surface. The float assembly can then be lowered into the well. Make sure that the indicator rod and float do not bind against the sides of the observation well (Fig. 10). The well is now ready for calibration.

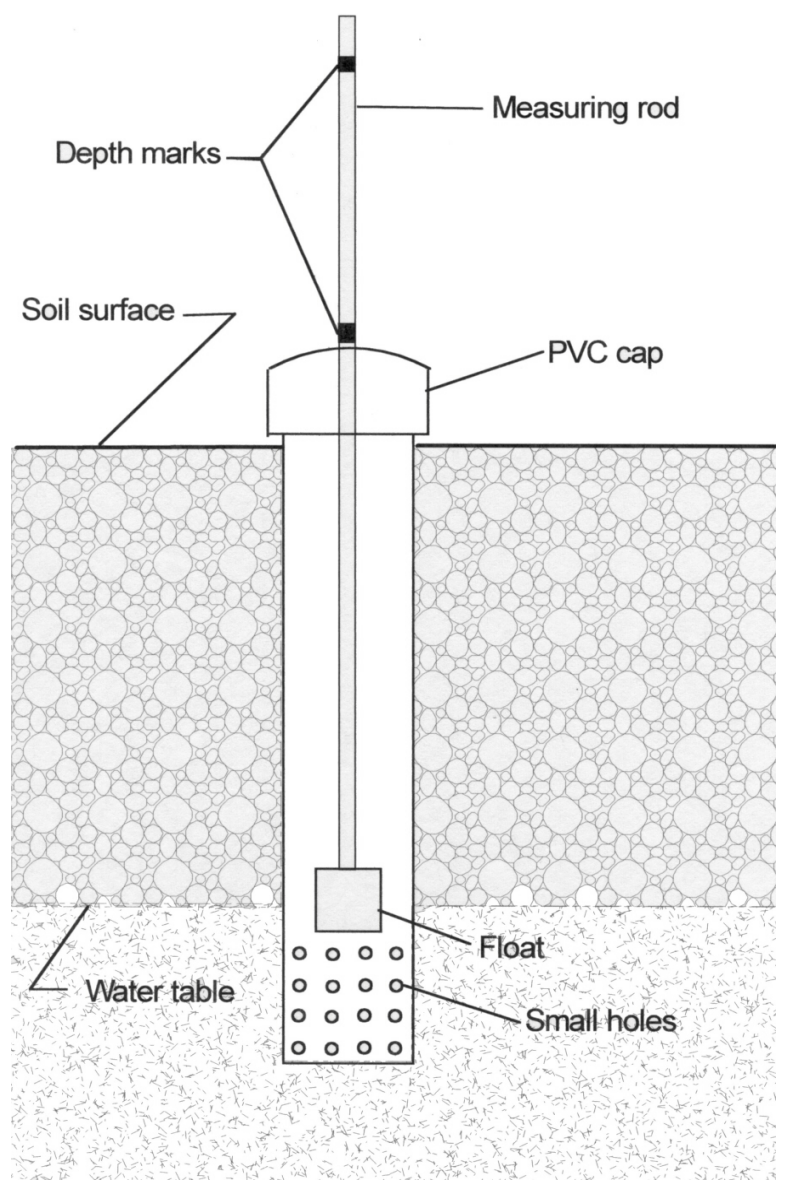

Figure 10. Schematic of completed observation well.

\section{Calibration}

Calibration should be performed when the water table is above the bottom of the well. The weight of the float assembly and rod will affect how much of the float is submerged before it floats. Typically, the float assemblies can respond to water levels less than $1 / 2$ inch above the bottom of the observation well.

The range of water table depths providing adequate upflux for tree water needs is largely determined by soil type. A mark on the indicator stake or rod should be made at the top of the well when the float is at the bottom of the well. This level is the reference mark for the well depth. The indicator stake or rod can then be marked with major divisions (feet) and minor divisions (inches) for easy reading of the water table depth. These rings can be painted at appropriate intervals using different colors for major and minor divisions. Marks painted at 2 inch increments provide enough accuracy for most users.

The mark at the upper level is dependent on the depth of the water furrow and root depth. The upper depth should be selected so that water does not pond in water furrows and it should be at least 6 inches below the bottom of the root zone to prevent root pruning.

The lower depth marks should be at points where the upflux of moisture is equal to the average daily evapotranspiration (ET). When the water table drops any lower, the tree will not receive the moisture it needs that day. The lower depth can be calculated as in the following example.

\section{$\underline{\text { Example (for a Winder soil) }}$}

Determine the water table depth required to supply typical citrus evapotranspiration requirements for a Winder series soil using typical average upflux values in Fig. 3 and evapotranspiration (ET) rates as given in Table 1.

Marks should be made on the indicator to show depths of $30 \mathrm{in.} \mathrm{(for} \mathrm{summer)} \mathrm{and} 37 \mathrm{in.} \mathrm{(for}$ winter months). These will be used to signal the need to start supplemental irrigation throughout the year. Assuming a root zone depth of 18 inches, another mark should be made to indicate a depth of 24 inches. Whenever the water table is closer to the surface than the 24-inch depth, steps should be taken to lower the water table. 
Observations over time will help to determine the water table level depth that will prevent root damage or excessive wetness in the root zone. In contrast, if the water table is allowed to drop to the point where there is not enough water moving upward to supply the moisture needs of the tree, additional irrigations may be required.

The zone between the maximum and minimum depths can be painted on the float assembly. A quick glance at the observation well (Fig 6) will indicate whether or not the water level is within desired limits.

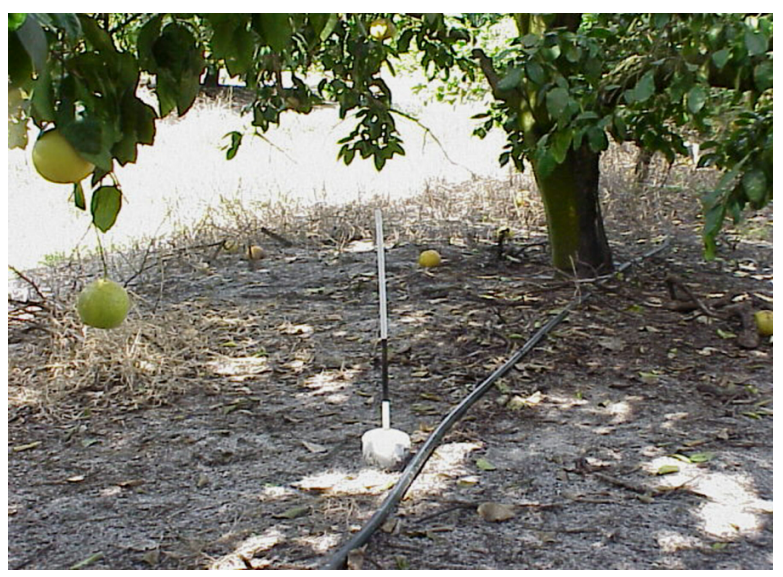

Figure 11. Observation well installed in citrus grove.

\section{Operation}

The water table observation well is an excellent tool for determining when to irrigate or when the water table is too high. The goal of water table management is to maintain the water table at a level just below the root zone but not high enough to cause root damage. After a soaking rain or irrigation cycle, water adheres to the surface of soil particles until all available pore spaces are filled. If the water table is close enough to the surface (as in the case of most flatwoods soils) this water may be available to the plant due to upflux, which generally lasts for several days as the water table gradually declines. If the water table is allowed to get too low, the soil dries out and the capillarity is broken. At this point, another rain or irrigation is needed.

Figure 12 shows the soil tensions at the 12-inch depth for a Wabasso series soil. During the afternoon hours, the soil water tension increases as water is removed from the soil to meet the evapotranspiration requirements of the tree. In the evenings, the upflux from the shallow water table is equal to the ET rate, so the soil tensions remain fairly constant. In the early morning hours the trees are not transpiring, therefore the soil tensions decrease at the 12-inch depth as upflux moves water from the water table to the drier soil above. The 0.5 inch rainfall on Wednesday afternoon (Fig. 12) wets the soil thoroughly at the 12-inch tensiometer depth, causing the soil tensions to drop to near zero.

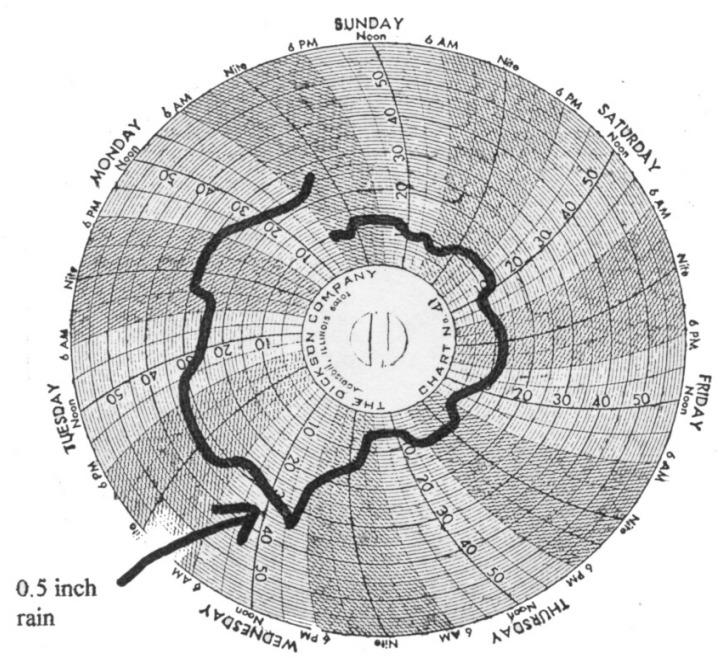

Figure 12. Graph of soil tension from a recording tensiometer for a Wabasso series soil at 12 inch depth.

While knowledge of the soil type can provide a reasonable prediction of water table behavior, observations and records from specific blocks will help one to understand how rainfall and irrigation affect the water table. This information can be used to develop an irrigation/drainage schedule that will optimize soil moisture availaility. Modify markings on the water table observation well indicator stake or rod to fine tune the observation well accuracy to tree conditions.

Maintenance of the water table observation wells is minimal. The painted rings may fade and require periodic re-painting. If an indicator stake or rod is suspected of erroneous readings, the assembly can be quickly removed to inspect the well. As routine maintenance, the observation wells should be closely inspected on an annual basis to ensure that they are functioning properly.

The purpose of water table observation wells is to assist in management of plant-available moisture through knowledge of fluctuating water tables in 
bedded faltwoods soils. Such information is helpful

for setting realistic irrigation and drainage schedules that avoid harmful over- or under-watering. For additional information on the installation, operation, and maintenance of water table observation wells, contact your local University of Florida Cooperative Extension Service Office, the nearest USDA-NRCS office, or your local Soil and Water Conservation District. 
Table 1. Typical water table depths required to supply citrus evapotranspiration requirements for a Winder series soil (using average values in Fig. 3).

\begin{tabular}{|c|c|c|c|c|c|}
\hline Month & $\begin{array}{c}\text { Typical } \\
\text { ET } \\
\text { (in./day) }\end{array}$ & $\begin{array}{l}\text { Water table } \\
\text { depth } \\
\text { (in.) }\end{array}$ & Month & $\begin{array}{l}\text { Typical } \\
\text { ET } \\
\text { (in./day) }\end{array}$ & $\begin{array}{l}\text { Water table } \\
\text { depth } \\
\text { (in.) }\end{array}$ \\
\hline Jan. & 0.07 & 37 & July & 0.19 & 30 \\
\hline Feb. & 0.09 & 36 & Aug. & 0.19 & 30 \\
\hline March & 0.12 & 34 & Sept. & 0.17 & 31 \\
\hline April & 0.15 & 32 & Oct. & 0.13 & 33 \\
\hline May & 0.17 & 31 & Nov. & 0.09 & 36 \\
\hline June & 0.18 & 30 & Dec. & 0.07 & 37 \\
\hline
\end{tabular}

